\title{
Phosphate and nitrate supplementations to evaluate the effect on cell biomass, intra and extracellular nodularin and nodulopeptin 901 produced by the cyanobacterium Nodularia spumigena KAC 66.
}

HAMEED, S., LAWTON, L.A., EDWARDS, C. 
Authors:

Shaista Hameed

Linda A. Lawton and

Christine Edwards

Phosphate and nitrate supplementations to evaluate the effect on cell biomass, intra and extracellular nodularin and nodulopeptin 901 produced by cyanobacterium, Nodularia spumigena KAC 66

Dr Shaista Hameed

Department of Environmental Sciences,

Sardar Bahadur Khan Women's University, Quetta,

Pakistan

AND

CyanoSol Research

School of Pharmacy \& Life Sciences

Sir Ian Wood Building

Robert Gordon University

Garthdee Road

Aberdeen, AB10 7GJ

United Kingdom

Prof Dr Linda A Lawton

CyanoSol Research

School of Pharmacy \& Life Sciences

Sir Ian Wood Building

Robert Gordon University

Garthdee Road

Aberdeen, AB10 7GJ

United Kingdom

Christine Edwards

CyanoSol Research

School of Pharmacy \& Life Sciences

Sir Ian Wood Building

Robert Gordon University

Garthdee Road

Aberdeen, AB10 7GJ

United Kingdom

\section{*Corresponding authors:}

\section{Dr Shaista Hameed}

Phone number: 0092-21-3312586747

Email: shaista_suhail2013@yahoo.com

\section{Prof Dr Linda A Lawton}

Phone number: 0044-1224 262823

Email address: 1.lawton@rgu.ac.uk 


\begin{abstract}
Blooms of the cyanobacterium, Nodularia spumigena occur regularly in the Baltic Sea typically producing a wide range of bioactive peptides including the hepatotoxin nodularin (NOD), spumigins, anabaeopeptins, and nodulopeptins (molecular weights;917, 901 and 899 Da). This study reports the production of intracellular and extracellular NOD and nodulopeptin 901 (the major secondary metabolites), at various nitrate and phosphorus concentrations produced by N. spumigena KAC 66, which was originally isolated from the Baltic Sea. The growth was observed by cell biomass and intracellular and extracellular peptides monitored by high performance liquid chromatography with photodiode array and mass spectrometry (HPLC-PDA-MS). In the present work it was investigated that the high concentrations of nitrate and phosphorus have a considerable effect on biomass and toxin levels produced by $N$. spumigena. In common with many studies, the maximum amount of NOD was retained within the cells during 5 weeks of growth. In contrast, as much as $\sim 40 \%$ of nodulopeptin 901 was excreted into the media throughout the duration of experiments. At 6.5 and $3.5 \mathrm{mg} \cdot \mathrm{L}^{-1}$ nitrate the maximum concentrations of peptide per unit biomass was $1.78 \mathrm{ng}$ NOD (in week 4) and1.42 $\mathrm{ng} \cdot \mu \mathrm{g}$ nodulopeptin 901 (in week 3) were detected. However, the high concentrations of both peptides were produced in the absence of nitrate. The phosphate experiment indicated growth and peptide production were dependent on availability of phosphorus. At $0 \mathrm{mg} \cdot \mathrm{L}^{-1}$ of phosphate an increased amount of intracellular (502.4 $\mathrm{ng} \cdot \mu \mathrm{g}$ biomass) nodulopeptin 901 was recorded. This report evaluates the effect of nutrients on the production of biomass and toxins, which may predict the formation and control of blooms of $N$. spumigena in the Baltic Sea. It also provides information to improve the growth conditions to produce high biomass and toxins under suitable conditions, which may be helpful in the research. The results from the current study will also be helpful to predict about possible blooms of $N$. spumigena in the Baltic Sea with reference to increase or decrease in nitrate and phosphate concentrations.
\end{abstract}

Keywords: Cyanobacterium, abiotic factors, toxins, biomass, Baltic Sea, nodularin, nodulopeptin 901

\title{
Introduction
}


The growth and bloom formation of microalgae in environments are controlled by abiotic and biotic factors such as light intensity, $\mathrm{pH}$, salinity, temperature and nutrient availability, especially nitrogen and phosphorous (Sivonen 1996). Nitrogen and phosphorus are primary nutrients, which are essential for the survival of all living organisms for the synthesis of primary metabolites such as proteins and nucleic acids and production of other biologically important compounds such as hepatotoxins, neurotoxins and lipopolysaccharde endotoxins (Lehtimäki et al. 1997). Over the last few decades human activities i.e. urbanisation, industrial and agricultural development, have contributed a major role in increasing cyanobacterial blooms in the Baltic Sea.The annual nitrogen fixation in the Baltic Sea occurs due to extensive blooms of diazotrophic/heterocystic cyanobacteria, toxic Nodularia spumigena along with non toxic Aphanizomenon flos-aquae (Mur et al.1999) and Anabaena spp. (Syn. Genus Dolichospermum; Halinen et al. 2008; Kutser et al. 2009; Brutemark et al. 2015), which is approximately equal to the total nitrogen input from atmospheric deposition, river run off and agricultural lands (Schneider et al. 2004). In the Baltic Sealow nitrogen and high phosphorus favour the blooms of these cyanobacteria (Lehtimäki et al. 1997; Mazur-Marzec et al. 2006) with moderate salinity (5-13 PSU; Mazur-Marzec et al. 2006). In general, cyanobacteria require N:P ratio as 7:1 which depends and varies from species to species (MazurMarzec et al. 2005). The diazotrophic bacteria are primarily limited by low N:P ratio (Mur et al. 1999; Stal et al. 2003). An increase or decrease in nitrogen and phosphorus concentrations affects cyanobacterial growth, community structure and toxin production (Lehtimäki et al. 1997; Henriksen 2005; MazurMarzec et al. 2005; Vintila and El-Shehawy 2010; Mazur-Marzec et al. 2013).

The variation in biotic and abiotic factors has great influence on increase or decrease of cell biomass, Chl$a$ and peptide production. The control on availability of nutrients can also be helpful to control cyanobacterial blooms and their toxin production in natural water bodies as well as production of high amounts of these peptides for laboratory based experiments. The nutrient concentrations can also inform about the developing blooms. A number of studies have been performed on the effects of abiotic factors (light, temperature, salinity, phosphate and nitrate) on the production cell biomass and intracellular NOD production. Like other nutrients phosphorus also plays an important part in increasing cyanobacterial biomass in the Baltic Sea. Enhanced phosphorus input from increased river run off since the early 1970s lead to the high phosphorus concentrations in the surface layers of the Baltic (Wasmund1997; Eilola et al. 2009) and resulted in an increase in intensity and duration of the N. spumigena blooms.

There is no information available regarding the effects of nitrate and phosphorus on the production extracellular NOD and intra and extracellular levels of recently characterised secondary metabolite, the nodulopeptin 901, 
produced by $N$. spumigena KAC 66 . This is the first study to determine the impact of nitrate and phosphate concentrations on the production of NOD and nodulopeptin 901 in N. spumigena KAC 66.

\section{Materials and methods}

In the present study the influence of abiotic factors (nitrate and phosphate) on the cell biomass and production of extra and intracellular nodularin (NOD) and nodulopeptin 901 in batch cultures of toxic cyanobacterium, N. spumigena KAC 66 was investigated. N. spumigena KAC 66 was obtained from Kalmar Collection Centre, Kalmar University, Sweden isolated from samples collected from Askö, Baltic Sea $(7 \%$ ).

For routine maintenance of stock culture, $50 \mathrm{~mL}$ of pure isolate of $N$. spumigena KAC 66 was inoculated in an Erlenmeyer flask (1L) filled with $500 \mathrm{~mL}$ autoclaved (Astell Scientific, UK; for 15 mins at $10^{5} \mathrm{~Pa}$ and $121^{\circ} \mathrm{C}$; Kawachi and Noël, 2005) blue green algal growth medium (BG-11; Allen and Stanier, 1968 modified by Stanier et al. 1971) to give a final culture volume of $\sim 550 \mathrm{~mL} / \mathrm{flask}$. The BG-11 was prepared in one fifth strength Instant Ocean artificial seawater (equal to 2\%o). The cultures were transferred under aseptic conditions in a laminar flow hood (Microflow, Biological Safety Cabinet, UK). Cultures were sparged by continuous slow aeration and kept under continuous cool white fluorescent illumination tubes (36 W) delivering 13.3 to $13.49 \mu \mathrm{mol}$ photons $\mathrm{m}^{-2} \mathrm{~s}^{-1}$ (LI-250A, light meter, USA) in a temperature controlled room $\left(22^{\circ} \mathrm{C}\right)$. The flasks were left for one month to obtain mass sufficient culture for experiments to use as stock culture (cell biomass $43 \mu \mathrm{g} \cdot \mathrm{mL}^{-1}$ and Chl- $a 0.033 \mu \mathrm{g} \cdot \mathrm{mL}^{-1}$ ).

In this experiment, a range of and $\mathrm{NO}_{3}^{-}-\mathrm{NO}_{2}^{-}$, nitrate and phosphate concentrations were tested, recorded from the different locations of the Baltic Sea (Lehtimäki et al. 1997; Repka et al. 2001; Stolte et al. 2002; Stal et al. 2003; Lilover and Stips 2008; Nausch and Nausch, 2011 and Vuorio et al. 2005).

\section{Nitrate concentrations}

To evaluate the effect of nitrate on cell biomass and peptide production various concentrations $(0,3.5$, $6.5,7.5,8.5$ and $\left.9.5 \mathrm{mg} \cdot \mathrm{L}^{-1}\right)$ of nitrate was used. For nitrate experiment 18 Erlenmeyer flasks $(500 \mathrm{~mL})$ were prepared with $350 \mathrm{~mL}$ of BG-11 (2\%) medium and adjusted at different concentrations of sodium nitrate $\left(\mathrm{NaNO}_{3}\right.$, Fisher Scientific, UK) in triplicate. All flasks were supplied by 2 silicon tube outlets and autoclaved for sampling and aeration.

\section{Phosphate concentrations}


To determine the effects of phosphorus on biomass and peptide production the experiment was performed in the Erlenmeyer flasks $(21$ x $500 \mathrm{~mL})$ prepared containing $350 \mathrm{~mL}$ of BG-11 medium (2\%o). The phosphate concentrations in each flask were adjusted to the required concentrations $(0,0.1,10,40$, 70, 100 and $120 \mathrm{mg} \cdot \mathrm{L}^{-1}$ ) using potassium phosphate (Fisher Scientific, UK). The Erlenmeyer flasks were supplied by 2 silicon tube outlets, one for sampling and the other to provide constant aeration. All flasks were autoclaved and left for cooling.

For all experiments flasks $(39 \times 100 \mathrm{~mL})$ were inoculated with $35 \mathrm{~mL}$ of 1 month old stock culture (cell biomass $43 \mu \mathrm{g} \cdot \mathrm{mL}^{-1}$ and Chl- $a 0.033 \mu \mathrm{g} \cdot \mathrm{mL}^{-1}$ ). The experiment was conducted in a temperature controlled room at $22^{\circ} \mathrm{C}$. All 39 flasks were kept under constant illumination from two cool white fluorescent tubes (36 W) delivering 13.5-14.5 $\mu \mathrm{mol}$ photons $\mathrm{m}^{-2} \mathrm{~s}^{-1}$ ). The nitrate and phosphate experiments were run in triplicate.

\section{Sampling and analysis of samples}

The sampling methods and analysis of samples for cell biomass, intra and extracellular NOD and nodulopeptin 901 for both experiments were same as described in Hameed et al. (2017). The sampling was done on day of inoculation (T0) and on weekly basis for 5 weeks (T1-T5; Hameed et al. 2017). For sampling all flasks were shaken manually and $25 \mathrm{~mL}$ was removed from each flask. Twenty $\mathrm{mL}$ sample was used for cell biomass and extracellular peptide level determination (Hameed et al. 2017), while 1.5 $\mathrm{mL}$ was used intracellular peptide level analysis (Hameed et al. 2017).

\section{Cell biomass determination}

Twenty $\mathrm{mL}$ of sample cultures of each treatment was taken and filtered through a pre-weighed GF/C glass microfiber filter discs $(55 \mathrm{~mm} \varnothing$, Whatman, UK) to determine cell biomass. The filter papers with cells were freeze dried over night using freeze dryer (HSC 500, Modulyo, Edwards, UK) at $-45^{\circ} \mathrm{C}$ and $10^{-}$ ${ }^{1} \mathrm{~m}$ bar. The filtrate was used to determine extracellular toxins (Hameed et al. 2017).

\section{Extraction of peptides}

The identification and quantification of peptides, NOD and nodulopeptin 901, were measured using Highperformance Liquid Chromatography Photodiode Array Mass Spectrometry (HPLC-PDA-MS; Hameed et al. 2017).

\section{a- Extracellular peptides}

Twenty $\mathrm{mL}$ filtrate of sample was used for the detection of extracellular toxins, released into the surrounding growth medium. The spent medium was freeze dried and re-suspended in $1 \mathrm{~mL} 80 \%$ 
MeOH: $\mathrm{H}_{2} \mathrm{O}(80: 20, \mathrm{v} / \mathrm{v})$ for $1 \mathrm{~h}$. The extracellular peptide levels were further analysed on UPLC-PDAMS.

\section{b- Intracellular peptides}

From $25 \mathrm{~mL}$ of the culture sample $1.5 \mathrm{~mL}$ was centrifuged at 13,000 x g (Eppendorf Centrifuge 5410, Germany) for 10 mins. The obtained pellets were vortexed with $150 \mu 1 \mathrm{MeOH}(80 \%)$ and left for 1 $\mathrm{h}$ for extraction to analyse on UPLC-MS.

\section{Analysis of NOD and nodulopeptin 901}

The system combined a Waters Alliance 2695 solvent delivery system, photodiode array detector (PDA, model 2996) and mass detector (ZQ 2000 MS), all supplied by Waters (Elstree, UK). The separation of peptides was achieved on a Sunfire $\mathrm{C}_{18}$ column ( $5 \mu \mathrm{m}$ particle size; $2.1 \mathrm{~mm}$ i.d. $150 \mathrm{~mm}$ long) maintained at $40^{\circ} \mathrm{C}$. The mobile solvent phase A was Milli-Q water with $0.05 \%$ (v/v) trifluoroacetic acid (TFA; Fisher Scientific, UK) and mobile solvent phase B was acetonitrile (Fisher Scientific, UK) with $0.05 \%$ TFA (v/v). Samples and standards were separated using a gradient increasing from 15 to $60 \%$ B for 25 minutes at a flow rate of $0.3 \mathrm{~mL} \cdot \mathrm{min}^{-1}$ followed by ramp up to $100 \% \mathrm{~B}$ and re-equilibration after 10 next minutes. Mass spectrometry was performed in positive ion electro-spray mode (ESI+), scanning from $\mathrm{m} / \mathrm{z}$ 100 to 1200 with a scan time of 2 seconds and inter-scan delay of 0.1 second ion source parameters. The sprayer voltage was set at $3.07 \mathrm{kV}$, and cone voltage $80 \mathrm{~V}$. The source temperature and desolvation temperatures were $100^{\circ} \mathrm{C}$ and $300^{\circ} \mathrm{C}$, respectively. MassLynx software v4.0 was used to control the instrument for data acquisition and processing. The photo diode array (PDA) was set to a resolution of $1.2 \mathrm{~nm}$ and data acquired from 200 to $400 \mathrm{~nm}$. The injection volume for standards and samples was 10 and $20 \mu \mathrm{l}$, respectively. Quantification of peptides was based on calibration with external standards NOD at $238 \mathrm{~nm}$ and nodulopeptin 901 at $210 \mathrm{~nm}$.

\section{Results}

\section{Analysis of cell biomass at nitrate concentrations}

The observations indicated that all nitrate concentrations favoured the growth of $N$. spumigena. An increased biomass (183.3 to $1068.3 \mu \mathrm{g} \cdot \mathrm{mL}^{-1}$ ) production was noted in $\mathrm{NaNO}_{3}$ free conditions. At all concentrations the highest cell biomass was observed in week 5 ranged from 1,068.3 to 2,223.3 $\mu \mathrm{g} \cdot \mathrm{mL}^{-}$ ${ }^{1}$. At $7.5 \mathrm{mg} \cdot \mathrm{L}^{-1}$ less cell biomass $\left(1,160.7 \mu \mathrm{g} \cdot \mathrm{mL}^{-1}\right)$ was recorded compared to $6.5,8.5$ and $9.5 \mathrm{mg} \cdot \mathrm{L}^{-}$

${ }^{1}\left(1,826.7,1973.3\right.$ and $2,223.3 \mu \mathrm{g} \cdot \mathrm{mL}^{-1}$, respectively). It showed that a rise in nitrate concentration increased the cell biomass production (Fig. 1). 

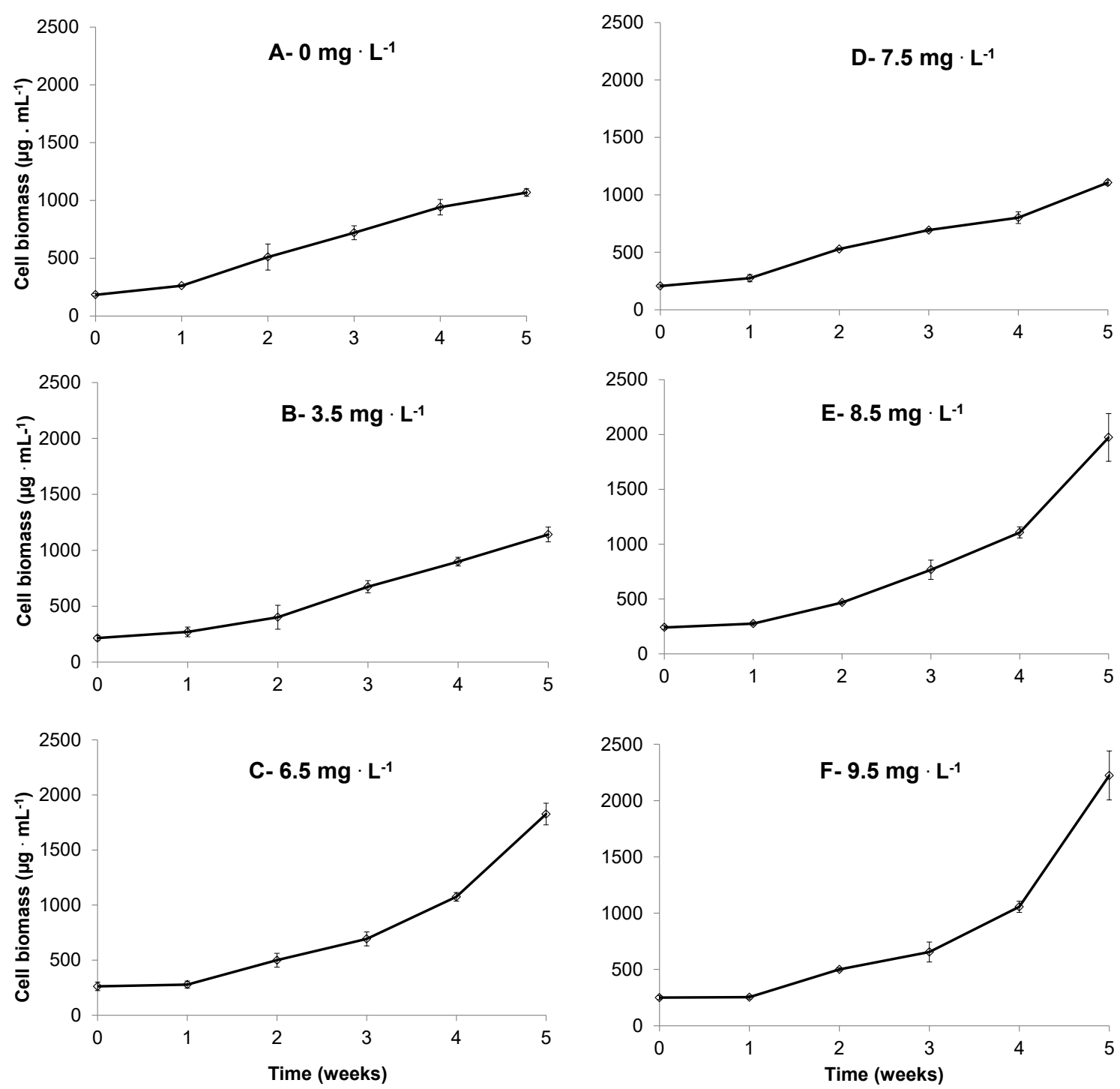

Figure 1. Cell biomass for cultures of $N$. spumigena KAC 66, grown at different concentrations of nitrate for 5 weeks at $22^{\circ} \mathrm{C}(\mathrm{n}=3$, bars $=1 \mathrm{SD})$.

\section{Analysis of peptides at different nitrate concentrations}

The results indicated that the $N$. spumigena can easily grow at low and high concentrations of nitrate with an increase in NOD concentrations in the cell biomass (Fig. 2). Combining the observations an increased in NOD per cell biomass $\left(0.1-1.78 \mathrm{ng}\right.$ NOD $\cdot \mu \mathrm{g}$ cell biomass $\left.{ }^{-1}\right)$ was noted from the first day of inoculation (T0) to week 3. It remained constant and then declined by week 5 (Fig. 2). In general week 2 had the highest amount of nodulopeptin 901 (Figs. 2A-F). At $3.5 \mathrm{mg} \cdot \mathrm{L}^{-1}$ nitrate concentration, the highest concentration of nodulopeptin 901 per cell biomass was recorded in week 2 compared to other nitrate concentrations i.e. $0,6.5,7.5,8.5$ and $9.5 \mathrm{mg} \cdot \mathrm{L}^{-1}$ (Figs. $\left.2 \mathrm{~A}-\mathrm{F}\right)$. 

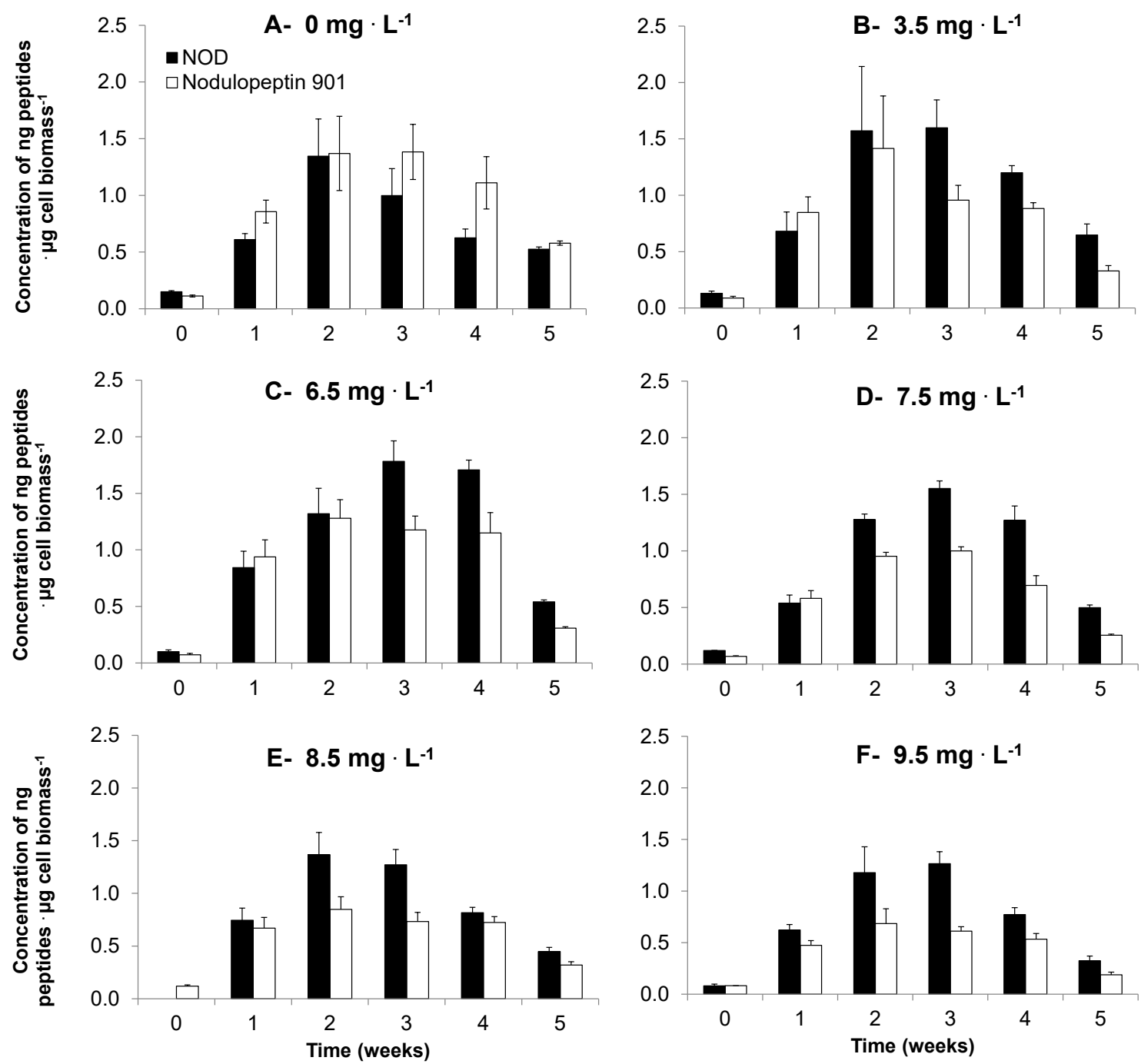

Figure 2. Concentration of peptides $\mu \mathrm{g}^{-1}$ cell biomass for cultures of $N$. spumigena KAC 66, grown at different concentrations of nitrate for 5 weeks at $22^{\circ} \mathrm{C}(n=3$, bars $=1 \mathrm{SD})$. A:- 0, B:- 3.5, C:- 6.5, D:- 7.5, E:- 8.5 and $F:-9.5 \mathrm{mg} \cdot \mathrm{L}^{-1}$.

At all concentrations of nitrate, the levels of intracellular NOD and nodulopeptin 901 showed an increase from week 1 to week 5 (Figs. 3 and 4). In contrast to the results from week 1-week 5 and at high nitrate level the lowest amount of intracellular NOD was recorded (Figs. 3A and F). At $6.5 \mathrm{mg} \cdot \mathrm{L}^{-1}$ the highest amount of intracellular NOD was observed by week 4, which decreased in week 5 (Fig. 3C). In comparison, at all other nitrate concentrations the week 3 and 4 supported the highest amount of intracellular NOD, which gradually decreased by week 5 (Fig. 3). At T0, the extracellular NOD was higher in week 1, which gradually decreased by week 3 and increased again in week 4 . In week 5 no extracellular NOD was detected (Fig. 3A). The media containing 3.5 and $6.5 \mathrm{mg} \cdot \mathrm{L}^{-1}$ nitrate showed similar pattern of extracellular NOD production, as time passed the amount of NOD increased from week 1-3 (Figs. 3B and C). This amount was found to be high $\left(16.7 \mathrm{ng} \cdot \mathrm{mL}^{-1}\right)$ in week 2 at $6.5 \mathrm{mg} \cdot \mathrm{L}^{-1}$ nitrate 
level (Fig. 3D). The extracellular NOD level at $9.5 \mathrm{mg}^{-1} \mathrm{~L}^{-1}$ was minimum in week 1 and $3,8.2$ and $8.3 \mathrm{ng}$ $\cdot \mathrm{mL}^{-1}$, respectively. This amount was maximum in week 2 (Fig. 3F). At all nitrate conditions, except at T0, no traces of extracellular NOD were observed in week 4 and 5.

Nodulopeptin 901 was detected intra and extracellularly in all nitrate conditions (0-9.5 mg $\mathrm{mL}^{-1}$; Fig. 4), which increased as time progressed. The observations indicated that at all nitrate concentrations, the higher intracellular nodulopeptin 901 levels were recorded in week 4, except at 7.5 $\mathrm{mg} \cdot \mathrm{L}^{-1}$. Analyzing all nitrate concentrations, $\mathrm{T} 0$ and $6.5 \mathrm{mg} \cdot \mathrm{L}^{-1}$ led to a higher intracellular nodulopeptin 901 concentrations in week 4 (Figs. 4A and C). The observations indicated an increase in extracellular nodulopeptin 901 production in all nitrate conditions, showed an exponential increase from week 1 to week 4, with a decrease in week 5 (Fig. 4). The extracellular nodulopeptin 901 concentrations at $\mathrm{T} 0$ and at $7.5 \mathrm{mg} \cdot \mathrm{L}^{-1}$, showed same trend but less amount was recorded in $7.5 \mathrm{mg} \cdot \mathrm{L}^{-1}$ (Figs. 4A and D). At 3.5 and $6.5 \mathrm{mg} \cdot \mathrm{L}^{-1}$ nitrate conditions a slight decrease in extracellular nodulopeptin 901 was recorded in week 3 (Figs. 4B and C). In the absence of nitrate the highest amount of extracellular nodulopeptin was recorded in week 4 (Fig. 4A). At the day of inoculation and in week 5 no traces or undetectable amount of extracellular NOD was observed and 100\% NOD retained within the cells (Table 1). During the whole experiment period low percentage of extracellular NOD was recorded from week 1 to week 4 ranged from 1-5\%. Between 3-29\% of total extracellular nodulopeptin 901 was found under all conditions. The percentage composition of nodulopeptin 901 represented that $71-97 \%$ retained intracellularly (Table 1). 

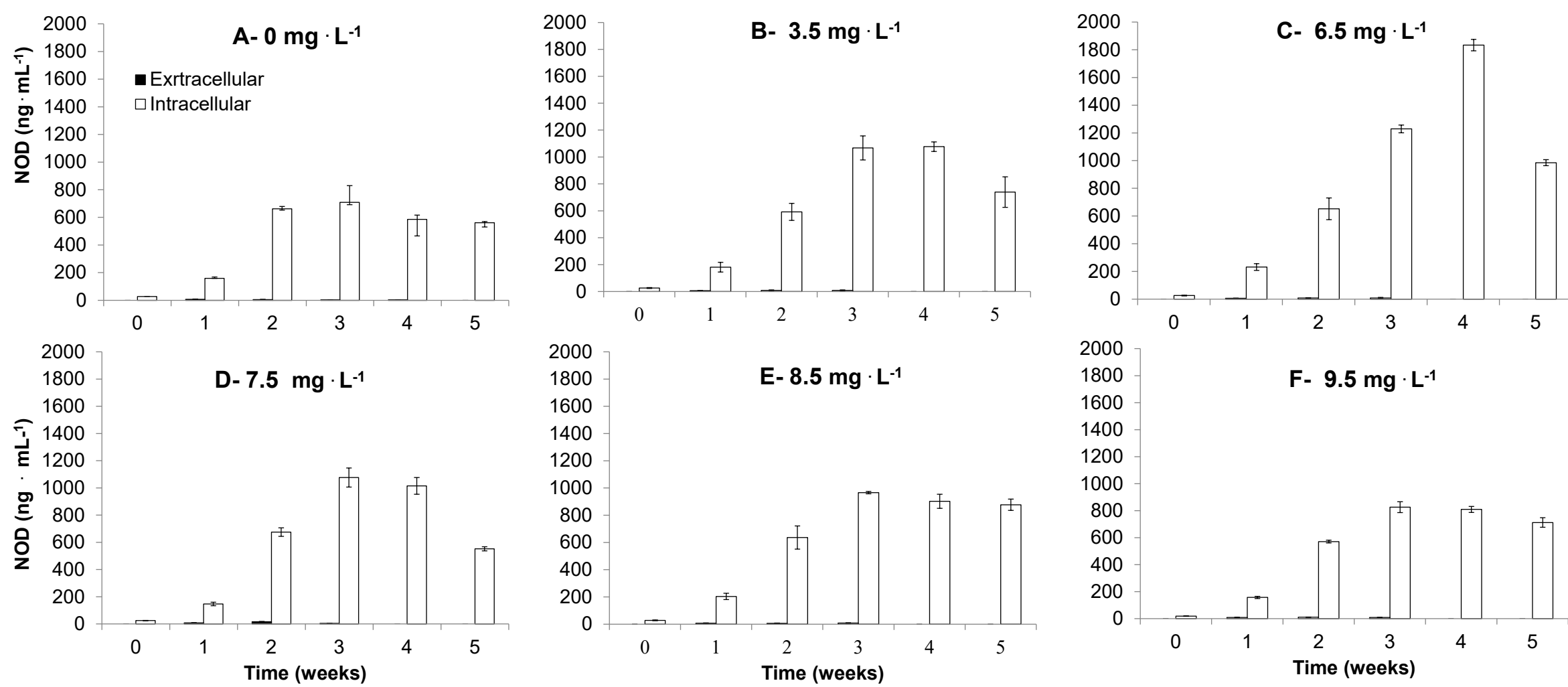

Figure 3.The Intra and extracellular levels of NOD at different concentrations of nitrate for cultures of $N$. spumigena $\mathrm{KAC} 66$ grown for 5 weeks at $22^{\circ} \mathrm{C}$ (n=3, bars $=1 \mathrm{SD}$ ). 

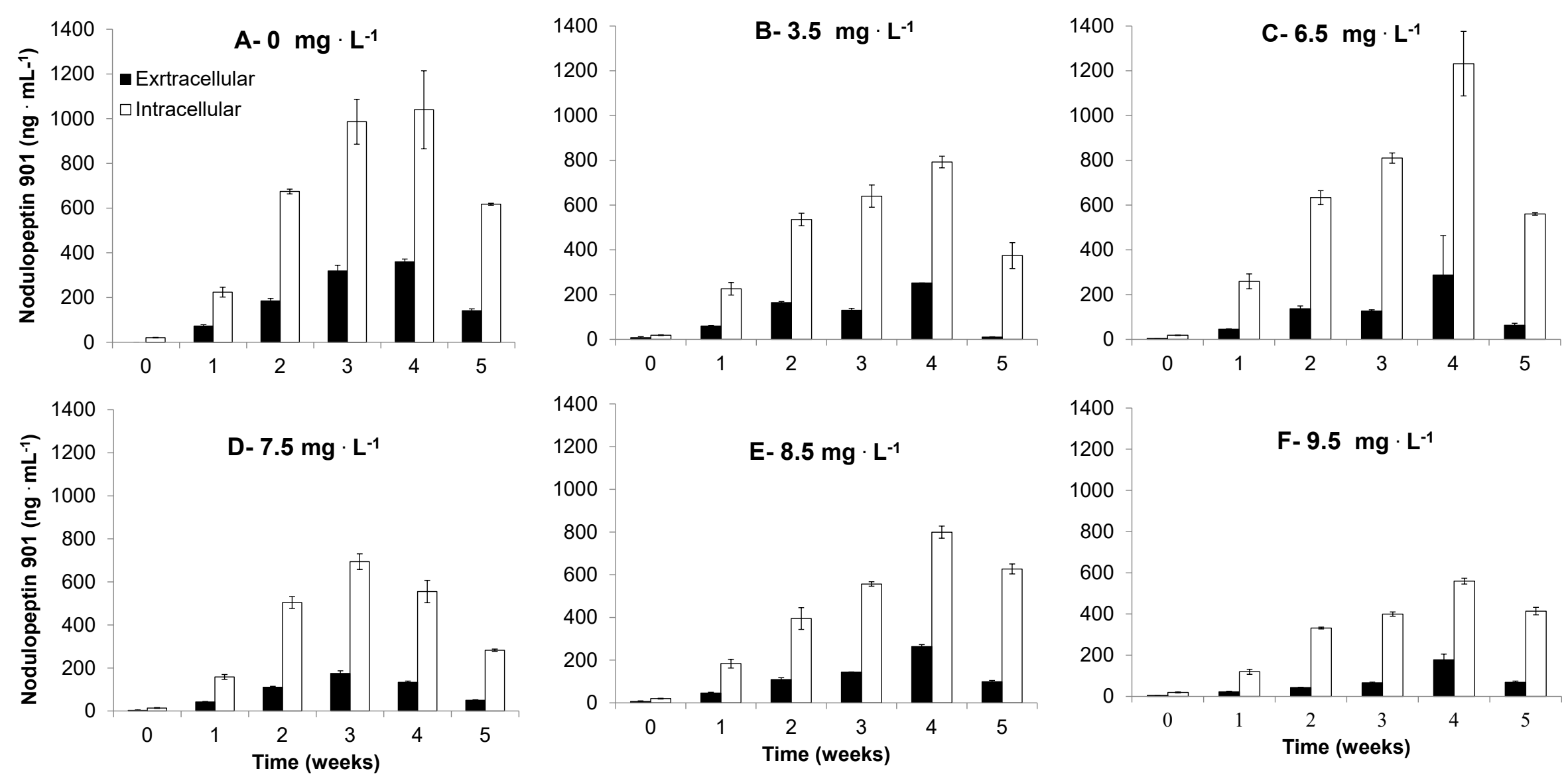

Figure 4. The Intra and extracellular levels of nodulopeptin 901 at different concentrations of nitrate for cultures of $N$. spumigena $\mathrm{KAC} 66$ grown for 5 weeks at $22^{\circ} \mathrm{C}$ $(n=3$, bars $=1 \mathrm{SD})$. 
Table 1. Percentages of NOD and nodulopeptin 901 in extra and intracellular levels for cultures of $N$. spumigena KAC 66 grown for 5 weeks at different nitrate concentrations ( $\mathrm{n} . \mathrm{d}=$ not detected).

\begin{tabular}{|c|c|c|c|c|c|}
\hline \multirow{2}{*}{$\begin{array}{c}\text { Time } \\
\text { (weeks) }\end{array}$} & \multirow{2}{*}{$\begin{array}{c}\text { Nitrate } \\
\text { conditions } \\
\left(\mathbf{m g} \cdot \mathbf{L}^{-1}\right)\end{array}$} & \multicolumn{2}{|c|}{ NOD (\%) } & \multicolumn{2}{|c|}{ Nodulopeptin 901 (\%) } \\
\hline & & Extracellular & Intracellular & Extracellular & Intracellular \\
\hline T0 & \multirow{6}{*}{ 0 } & n.d. & 100 & n.d. & 100 \\
\hline T1 & & 4 & 96 & 24 & 76 \\
\hline $\mathrm{T} 2$ & & 1 & 99 & 22 & 78 \\
\hline T3 & & 0 & 100 & 24 & 76 \\
\hline T4 & & 1 & 99 & 26 & 74 \\
\hline T5 & & n.d. & 100 & 19 & 81 \\
\hline T0 & \multirow{6}{*}{3.5} & n.d. & 100 & 29 & 71 \\
\hline T1 & & 4 & 96 & 21 & 79 \\
\hline $\mathrm{T} 2$ & & 2 & 98 & 23 & 77 \\
\hline T3 & & 1 & 99 & 17 & 83 \\
\hline T4 & & n.d. & 100 & 24 & 76 \\
\hline T5 & & n.d. & 100 & 3 & 97 \\
\hline T0 & \multirow{6}{*}{6.5} & n.d. & 100 & 21 & 79 \\
\hline T1 & & 3 & 97 & 15 & 85 \\
\hline $\mathrm{T} 2$ & & 1 & 99 & 18 & 82 \\
\hline T3 & & 1 & 99 & 14 & 86 \\
\hline T4 & & n.d. & 100 & 19 & 81 \\
\hline T5 & & n.d. & 100 & 10 & 90 \\
\hline T0 & \multirow{6}{*}{7.5} & n.d. & 100 & 17 & 83 \\
\hline T1 & & 5 & 95 & 21 & 79 \\
\hline $\mathrm{T} 2$ & & 2 & 98 & 18 & 82 \\
\hline T3 & & 0 & 100 & 20 & 80 \\
\hline T4 & & n.d. & 100 & 19 & 81 \\
\hline T5 & & n.d. & 100 & 15 & 85 \\
\hline T0 & \multirow{6}{*}{8.5} & n.d. & 100 & 24 & 76 \\
\hline T1 & & 4 & 96 & 20 & 80 \\
\hline $\mathrm{T} 2$ & & 1 & 99 & 22 & 78 \\
\hline T3 & & 1 & 99 & 20 & 80 \\
\hline T4 & & n.d. & 100 & 25 & 75 \\
\hline T5 & & n.d. & 100 & 14 & 86 \\
\hline T0 & \multirow{6}{*}{9.5} & n.d. & 100 & n.d. & n.d. \\
\hline T1 & & 5 & 95 & 16 & 84 \\
\hline T2 & & 2 & 98 & 12 & 88 \\
\hline T3 & & 1 & 99 & 14 & 86 \\
\hline T4 & & n.d. & 100 & 24 & 76 \\
\hline T5 & & n.d. & 100 & 14 & 86 \\
\hline
\end{tabular}

\section{Analysis of cell biomass at different phosphate concentrations}

At concentrations of $0,0.1,40,70$ and $100 \mathrm{mg} \cdot \mathrm{L}^{-1}$ phosphate, N. spumigena showed indistinguishable growth, following by an increase in week 2 and later a decrease (Figs. 5B, D, E and F). However, in contrast at 10 and $120 \mathrm{mg} \cdot \mathrm{L}^{-1}$ the amount of cell biomass increased throughout the growth period (Figs. 5C and $\mathrm{G}$ ). In $\mathrm{PO}_{4}^{-3}$ free cultures the lowest cell biomass values were recorded (Fig. 5A) and $120 \mathrm{mg} \cdot \mathrm{L}^{-1}$ supported the maximum cell in week 5 (Fig. 5G). 

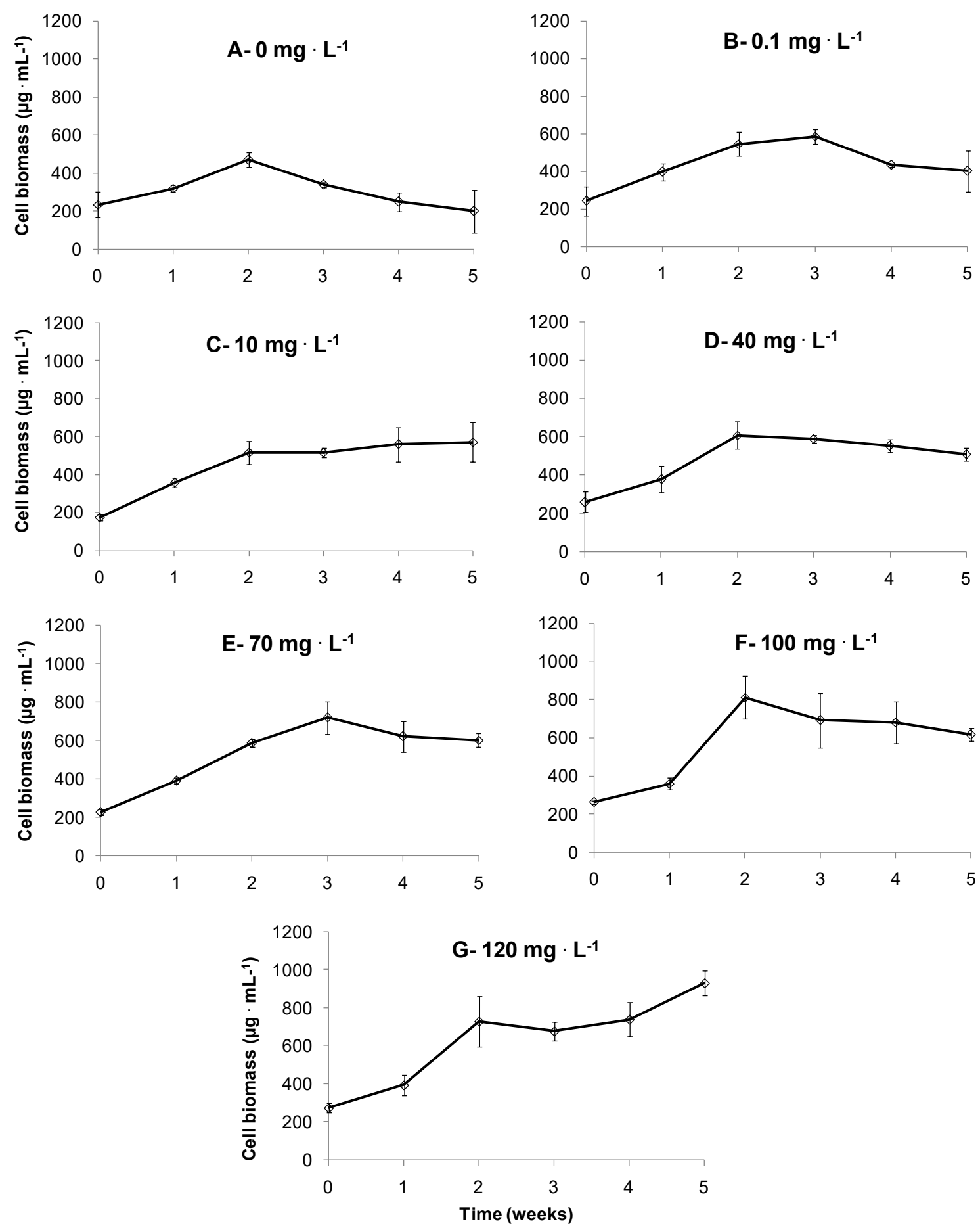

Figure 5.Cell biomass for cultures of $N$. spumigena KAC 66, grown at different concentrations of phosphate for 5 weeks at $22^{\circ} \mathrm{C}(\mathrm{n}=3$, bars $=1 \mathrm{SD})$.

\section{Analysis of peptides at different phosphate concentrations}

Peptide production per unit biomass showed a similar trend across all phosphate treatments, an initial increase, later NOD and nodulopeptin 901 levels in cell biomass decreased (Figs. 6A-F). In comparison with other weeks the observations indicated that the week 2 had the highest NOD (2.9-4.2 $95 \mathrm{ng} \cdot \mu \mathrm{g}$ 
cell biomass $\left.^{-1}\right)$ and nodulopeptin $901\left(0.9-1.1 \mathrm{ng} \cdot \mu \mathrm{g}\right.$ cell biomass $\left.{ }^{-1}\right)$ concentrations in cells biomass. It was also noted that in the both experiments, the peptide per cell quota decreased over time as shown in Figs 2 and 6, but concentrations per volume remained quite constant following initial increase.
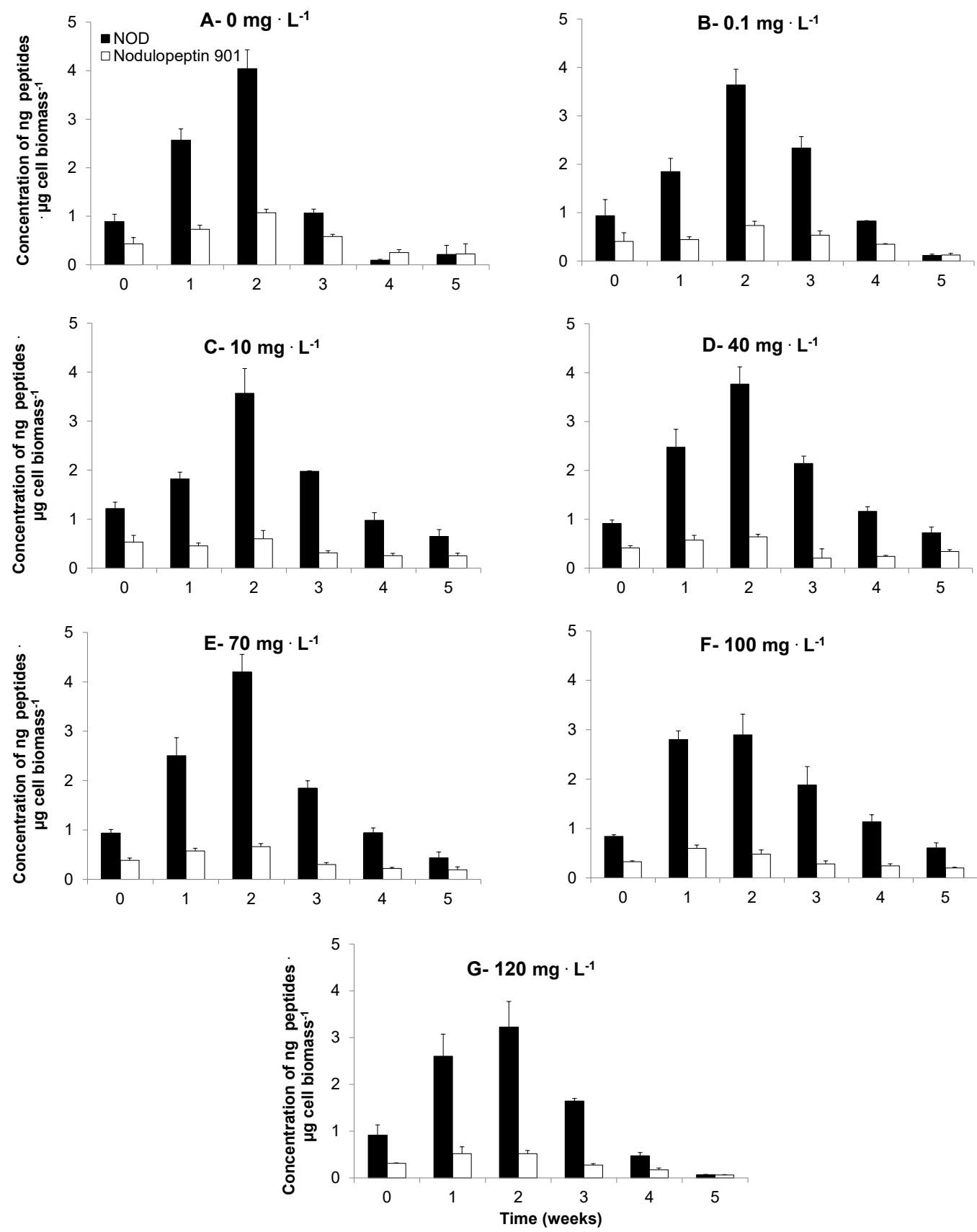

Figure 6. Concentration of peptides $\mu \mathrm{g}^{-1}$ cell biomass for cultures of $N$. spumigena KAC 66, grown at different concentrations of phosphate for 5 weeks at $22^{\circ} \mathrm{C}(\mathrm{n}=3$, bars $=1 \mathrm{SD})$. A:- 0, B:- 0.1, C:- 10 , D:- 40, E:- 70, F:- 100 and G:- $120 \mathrm{mg} \cdot \mathrm{L}^{-1}$.

In all treatments, based on concentration of peptide per $\mathrm{mL}$, the highest concentrations of NOD were found intracellularly (Fig. 7). The intracellular NOD concentration in phosphate deficient medium, 
was very low in week 4 and 5 (Fig. 7A). In all experimental conditions maximum concentrations of intracellular NOD were detected in week 2 (Fig. 7), which then gradually decreased until week 5 . The relative proportion of extracellular NOD was very low compared to concentrations of NOD within the cell. At 0,10 and the highest $120 \mathrm{mg} \cdot \mathrm{L}^{-1}$ phosphate conditions, the concentration of extracellular NOD was lowest in last three weeks (Figs. 7A, C and G). At T0 an increased extracellular NOD was observed till week 3 followed by a decrease in week 4 and 5 (Fig. 7A). In $40 \mathrm{mg} \cdot \mathrm{L}^{-1}$ this peptide started decrease in week 3 and 4 with a slight increase in week 5 (Fig. 7D). At $100 \mathrm{mg} \cdot \mathrm{L}^{-1}, N$. spumigena released the highest amount of NOD in surrounding medium (Fig. 7F), although levels were still relatively low. Comparing all conditions of phosphate on concentrations of intracellular nodulopeptin 901 resulted in the same trend; increase upto week 2, followed by a decrease (Fig. 8). At all concentrations an elevated level of this peptide was noted in week 2, with a slight increase in week 5 at $40 \mathrm{mg} \cdot \mathrm{L}^{-1}$ (Fig. 8D). The levels of this extracellular peptide showed the same trend and decreased over time. In general week 3 and 4 supported the maximum release of nodulopeptin 901 in growth medium. At the day of inoculation the highest nodulopeptin 901 was observed in week 3 (Fig. 8A). Forty $\mathrm{mg} \cdot \mathrm{mL}^{-1}$ supported an increase in extracellular nodulopeptin 901 as time passed (Fig. 8D). At 0, 70, 100 and $120 \mathrm{mg} \cdot \mathrm{L}^{-1}$ phosphate conditions the cultures demonstrated the same pattern with an increase in 3 and 4 (Figs. 8C, E, F and G).

Between $96-100 \%$ of total NOD was found intracellularly under all conditions and it was not release in surrounding medium (Table 2). Extracellular nodulopeptin 901 released in surrounding medium (11-49\%) at all phosphate conditions and much amount retained (51-89\%) within the cells. At $0,0.1$ and $70 \mathrm{mg} \cdot \mathrm{L}^{-1}$ conditions an equilibrium were observed between extra and intracellular nodulopeptin 901 concentrations in week 4 . 

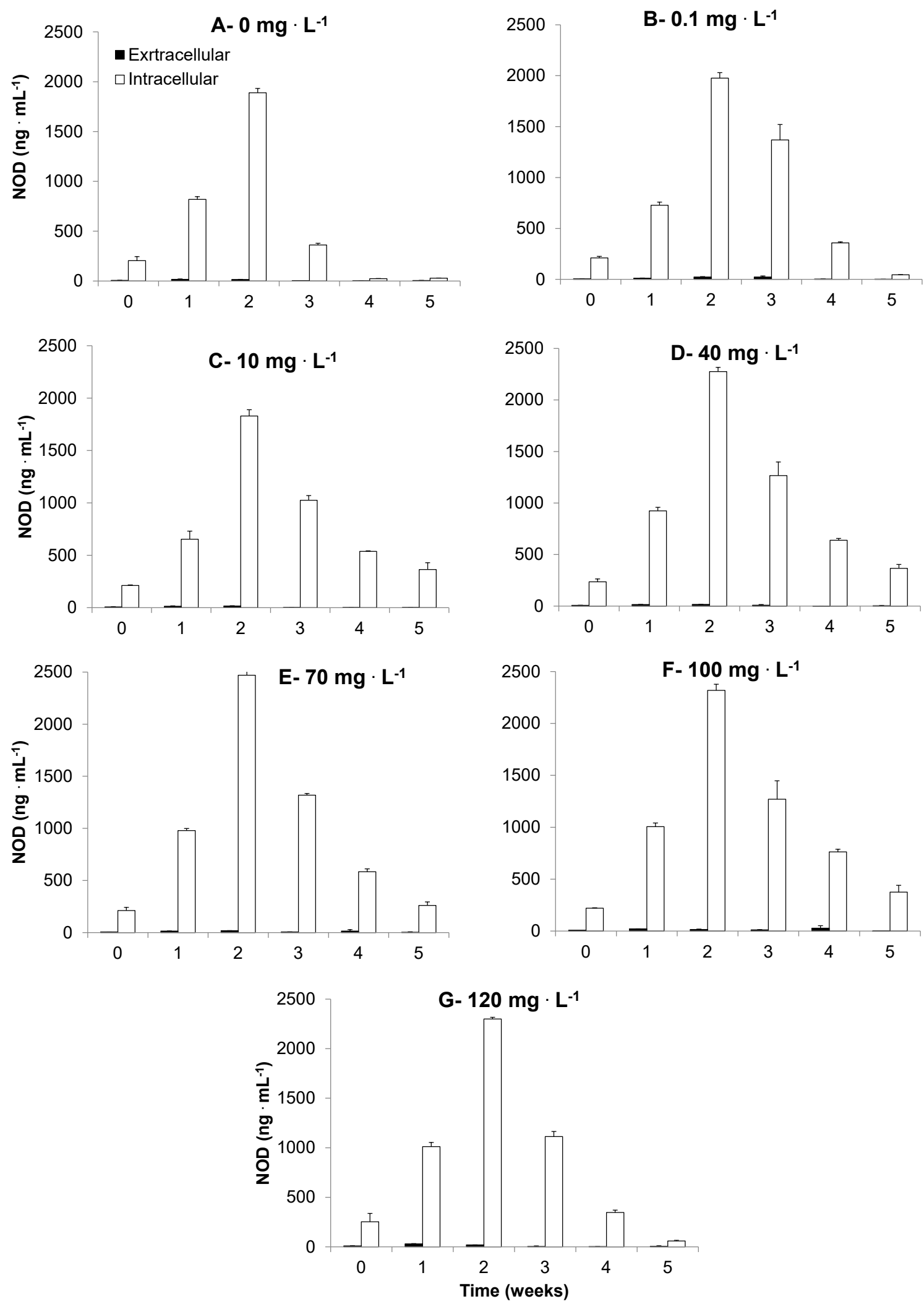

Figure 7. The intra and extracellular levels of NOD at different concentrations of phosphate for cultures of $N$. spumigena $\mathrm{KAC} 66$ grown for 5 weeks at $22^{\circ} \mathrm{C}(\mathrm{n}=3$, bars $=1 \mathrm{SD})$. 

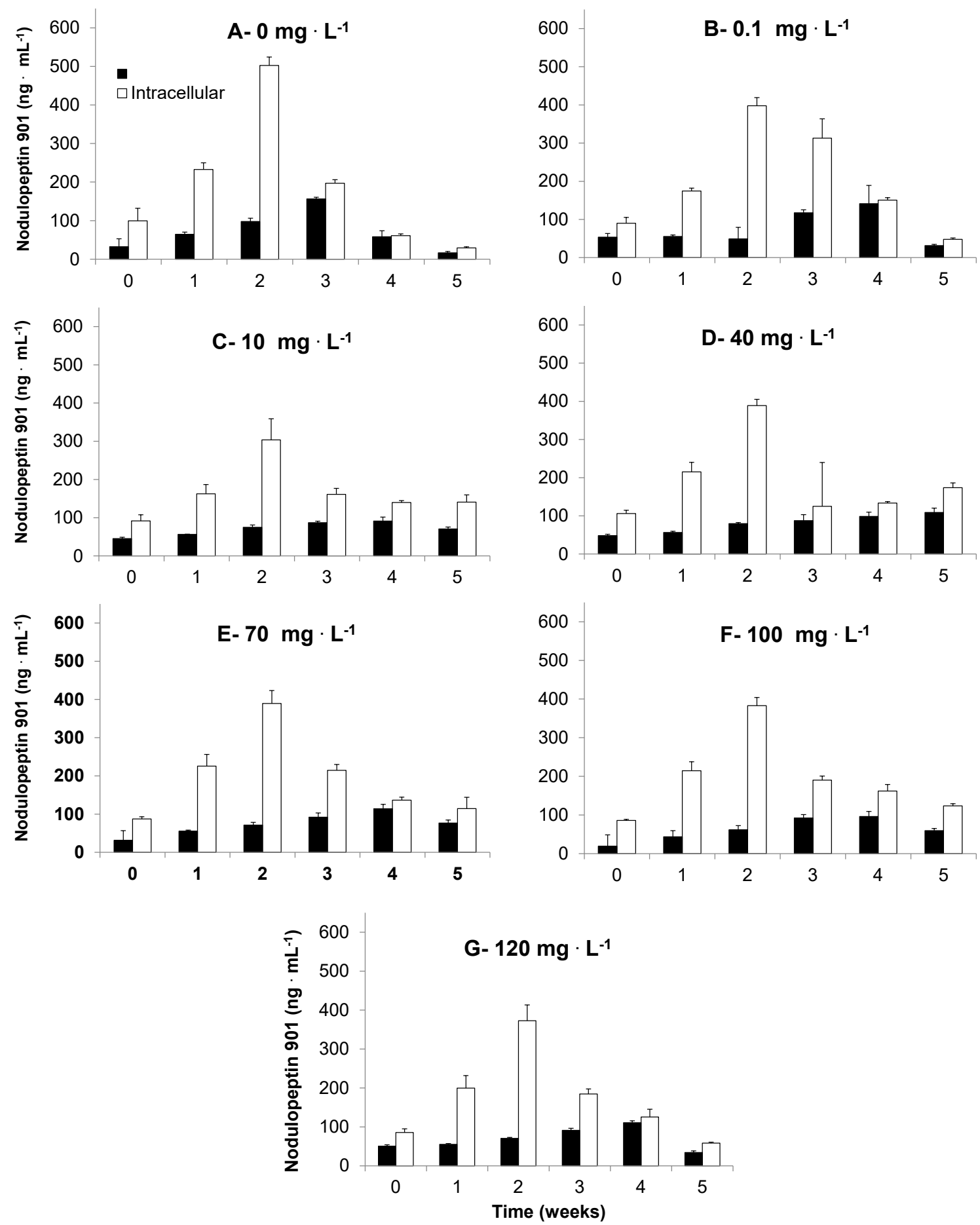

Figure 8.The intra and extracellular levels of nodulopeptin 901 at different concentrations of phosphate for cultures of $N$. spumigena $\mathrm{KAC} 66$ grown for 5 weeks at $22^{\circ} \mathrm{C}(\mathrm{n}=3$, bars $=1 \mathrm{SD})$. 
Table 2. Percentages of NOD and nodulopeptin 901 in extra and intracellular levels for cultures of $N$. spumigena KAC 66 grown for 5 weeks at different phosphate concentrations (n.d $=$ not detected).

\begin{tabular}{|c|c|c|c|c|c|}
\hline \multirow{2}{*}{$\begin{array}{c}\text { Time } \\
\text { (weeks) }\end{array}$} & \multirow{2}{*}{$\begin{array}{c}\text { Phosphate } \\
\text { conditions } \\
(\mathrm{mg} / \mathrm{l})\end{array}$} & \multicolumn{2}{|c|}{ NOD (\%) } & \multicolumn{2}{|c|}{ Nodulopeptin 901 (\%) } \\
\hline & & Extracellular & Intracellular & Extracellular & Intracellular \\
\hline To & \multirow{6}{*}{$\mathbf{0}$} & 3 & 97 & 25 & 75 \\
\hline T1 & & 2 & 98 & 22 & 78 \\
\hline T2 & & 1 & 99 & 16 & 84 \\
\hline T3 & & 1 & 99 & 44 & 56 \\
\hline T4 & & 6 & 94 & 49 & 51 \\
\hline T5 & & 13 & 87 & 36 & 64 \\
\hline To & \multirow{6}{*}{0.1} & 2 & 98 & 37 & 63 \\
\hline T1 & & 2 & 98 & 24 & 76 \\
\hline $\mathbf{T 2}$ & & 1 & 99 & 11 & 89 \\
\hline T3 & & 2 & 98 & 27 & 73 \\
\hline T4 & & 1 & 99 & 48 & 52 \\
\hline T5 & & 3 & 97 & 40 & 60 \\
\hline To & \multirow{6}{*}{10} & 3 & 97 & 33 & 67 \\
\hline T1 & & 2 & 98 & 26 & 74 \\
\hline T2 & & 1 & 99 & 20 & 80 \\
\hline T3 & & 0 & 100 & 35 & 65 \\
\hline T4 & & 0 & 100 & 40 & 60 \\
\hline T5 & & 0 & 100 & 33 & 67 \\
\hline To & \multirow{6}{*}{40} & 3 & 97 & 31 & 69 \\
\hline T1 & & 2 & 98 & 21 & 79 \\
\hline $\mathbf{T 2}$ & & 8 & 92 & 17 & 83 \\
\hline T3 & & 1 & 99 & 41 & 59 \\
\hline T4 & & 0 & 100 & 42 & 58 \\
\hline T5 & & 1 & 99 & 39 & 61 \\
\hline To & \multirow{6}{*}{70} & 3 & 97 & 27 & 73 \\
\hline T1 & & 2 & 98 & 20 & 80 \\
\hline T2 & & 1 & 99 & 15 & 85 \\
\hline T3 & & 0 & 100 & 30 & 70 \\
\hline T4 & & 2 & 98 & 45 & 55 \\
\hline T5 & & 1 & 99 & 40 & 60 \\
\hline To & \multirow{6}{*}{100} & 3 & 97 & 19 & 81 \\
\hline T1 & & 2 & 98 & 17 & 83 \\
\hline T2 & & 1 & 99 & 14 & 86 \\
\hline T3 & & 1 & 99 & 33 & 67 \\
\hline T4 & & 4 & 96 & 37 & 63 \\
\hline T5 & & 0 & 199 & 33 & 67 \\
\hline To & \multirow{6}{*}{120} & 4 & 96 & 37 & 63 \\
\hline T1 & & 3 & 97 & 22 & 78 \\
\hline $\mathbf{T 2}$ & & 1 & 99 & 16 & 84 \\
\hline T3 & & 0 & 100 & 33 & 67 \\
\hline T4 & & 4 & 96 & 47 & 53 \\
\hline T5 & & 8 & 92 & 37 & 63 \\
\hline
\end{tabular}




\section{Discussion}

The effect of nutrient status on occurrence of blooms of N. spumigena in the Baltic Sea is still a debated topic. The current study is a step towards the effect of nutrients on the production of peptides produced by N. spumigena KAC 66, isolated from the Baltic Sea. It was observed that the intra and extracellular levels of peptides are triggered and regulated by availability of nitrate and phosphate contents. A look into the results of the current study it was monitored that the highest cell biomass was recorded in week 5 at the highest concentrations of nitrates. Vintila and El-Shehawy (2010) mentioned that N. spumigena strains isolated from the Baltic Sea, did not respond considerably to nitrate rich cultures. They suggested that $N$. spumigena strains are not efficient at utilising dissolved inorganic nitrogen (DIN) compared with other nitrogen fixing cyanobacteria. In the Baltic Sea N. spumigena produces blooms in N limited areas (Stal et al. 2003) and seem to be affected by other factors i.e. salinity (Voß et al. 2013; Hameed et al. 2017; Teikari et al. 2018), temperature and phosphorus (Vintila and ElShehawy 2010). It has been suggested that due to geographical distribution and variability in the genetic background within N. spumigena strains respond differently (Vintila and El-Shehawy 2010). Stal et al. (2003) and Kivi et al. (1993) speculated that in late summer N. spumigena forms blooms in nutrient limited conditions in the Baltic Sea. According to them it is an assumption that low N:P ratio in the Baltic Sea water promotes the cyanobacterial growth. However, it seems to be opposite in this laboratory based study the highest cell biomass was observed at high concentrations of $\mathrm{NO}_{3}^{-}$. Stal et al. (2003) suggested that abundance of $\mathrm{N}_{2}$-fixing cyanobacteria in the Baltic Sea is due to low N:P ratios. According to Bianchi et al. (2000) the blooms of currently $\mathrm{N}_{2}$-fixing cyanobacteria in the Baltic Sea, is not due to human activities but it is a natural phenomenon since 7000 years. These blooms start due to high amount of phosphorus, leaching from sediments and phosphorus rich seawater. Other than nitrogen and phosphate; salinity and temperature also effect on the distribution and abundance of species and toxin production by N. spumigena KAC 66 (Hameed et al. 2017; Teikari et al. 2018) and Anabaena spp. (Syn. Genus Dolichospermum; Brutemark et al. 2015; Halinen et al. 2007) isolated from the Baltic Sea.

At lower nitrate conditions and control cultures, an increased intracellular NOD levels were observed, this hypothesis is supported by laboratory based experiments that Anabaena spp. (Rapala et al. 1997) 
and N. spumigena (Lehtimäki et al. 1997) demonstrated an increase in microcystin and nodularin under $\mathrm{N}_{2}$ limited conditions, respectively. In another study, Vuorioet al. (2005) performed an experiment on the effect nitrogen and phosphorus ratio on the phytoplankton community structure in mesocosm, Archipelago Sea, Northern Baltic Sea. In the end of 3 weeks experiment they found that microcystin and NOD increased with increasing biomass of Anabaena spp. and N. spumigena. The results of this study for production of NOD were consistent with other work where nutrient limitations resulted in a decrease in the production since biosynthesis consumes significant energy and cells use limited nutrient sources to survive. Vezie et al. (2002) did a comparative study between toxic and non toxic Microcystis spp. under variable nitrogen $\left(0.84-84 \mathrm{mg} \cdot \mathrm{L}^{-1}\right)$ and phosphorus $\left(0.05-5.5 \mathrm{mg} \cdot \mathrm{L}^{-1}\right)$ conditions. They noted that in nutrient limited conditions toxic strains reduce the production of toxins and use resources for their growth only. Therefore, non toxic Microcystis strain grew better than toxic strain. It might be that the biosynthesis of hepatotoxic microcystin requires additional energy consumption during toxin production process.

Cyanobacterial strains have ability to store phosphorus and can maintain their growth and toxin production under phosphorus deficient conditions (Karjalainen 2005). This was demonstrated in this study where $N$. spumigena grew under all phosphorus conditions. At the highest phosphorus level a linear increase in cell biomass was recorded compared with other conditions. It shows that the high phosphorus concentration supported the growth of $N$. spumigena. The blooms samples of Aphanizomenon flos-aquae and N. spumigena collected from the Gulf of Finland, Baltic Sea, grew to high biomass under high phosphorus and low N:P ratios (Kononen et al. 1996). The laboratory based experiments also indicated that the inorganic phosphorus (Pi) enriched conditions have exponential effect on growth, carbon and $\mathrm{N}_{2}$ fixation by $N$. spumigena. It indicates that the Baltic Sea contained all nutrients, which support the bloom formation of $N$. spumigena (Olofsson et al. 2016) and Anabaena sp. (Teikari et al. 2015) limited by phosphorus Olofsson et al. (2016) also mentioned that the high biomass and total $\mathrm{N}_{2}$ fixation ability of $N$. spumigena was high under elevated phosphorus concentrations in the Baltic Sea.

In present study the high cell biomass, intra and extracellular NOD and nodulopeptin 901 concentrations were found in the end of log phase and in beginning of stationary phase in control to 
high phosphorus conditions, which followed by a decline. Microcystins, anabaenopeptilides and anabaenopeptins, produced by Anabaena strain 90, showed the highest peptide concentrations in the medium phosphate levels (Repka et al. 2004). Similar results were found for microcystins at the middle of the growth period (Sivonen and Jones, 1990). In general, in this study, at all phosphorus conditions extracellular NOD and nodulopeptin 901 (except in control medium) a decline of toxins was observed with incubation time. Lehtimäki (2000) reported that at different phosphorus conditions extracellular NOD concentrations increased with increasing time. Studies on both phosphorus starved inocula of strains represented the slow growth by hepatotoxic $N$. spumigena and stimulated growth by non-toxic A. flos-aquae, from the Baltic Sea. It is suggested that in deficient medium non toxic strains grow well because they do not spend energy on the biosynthesis of hepatotoxins (Lehtimäki et al. 1997).

In the present study, the majority of NOD was retained within the cells during late log phase and early stationary growth phases consistent with other cyanotoxins. It may also be due to the cell death, the toxins could not be released in the surrounding media. While concentrations of nodulopeptin 901 indicated a negative correlation; a decrease of cell contents showed an increase of extra and intracellular nodulopeptin 901 contents. Carmichael et al. (1988) and Lehtimäki et al. (1997) mentioned that $N$. spumigena collected from the Baltic Sea, showed a positive correlation with extra and intracellular toxins. Under favourable conditions anatoxin-a (Rapala et al. 1993) and microcystin (Sivonen 1990; Rapala et al.1997) mostly retained within the cells. Vezie et al. (2002) also noted that when toxic Microcystis cultures at late log or early stationary phases, the maximum amount of microcystin retained within the cell, while growing in different $\mathrm{N}$ and $\mathrm{P}$ concentrations. In the present study at high concentrations of nitrate the lower amounts of intra and extracellular peptides were recorded. Lehtimäki et al. (1997) found that at high inorganic $\mathrm{N}_{2}$ concentrations lower amount of intracellular NOD was found in nitrogen fixing $N$. spumigena. No data is available on the effects of environmental factors on production of intra and extracellular nodulopeptin 901.

In this study in all experiments a fluctuation in cell biomass was observed, probably due to start of death phase of cultures and died cells were measured as cell biomass. The second reason was that the nitrate contents remained on filter discs, used for filtration to determine cell biomass, which may cause variation in cell biomass (Lehtimäki et al. 1997; Hobson and Fallowfield 2003). Many scientists also 
recommended that Chl- $a$ pigments are good to determine biomass of growing strains (Becker 1994; Lehtimäki et al.1997; Lawton, 1999; Gupta et al. 2002; Murphyet al. 2005).

In general, different nitrate and phosphate conditions had similar effects on intra and extracellular peptide levels, they decreased with increasing time. The absence of nitrate in the medium had a significant negative effect on the cell biomass concentrations and total NOD production (intra and extracellular). However, intra and extracellular nodulopeptin 901 were high under this condition. In phosphate deficient medium $N$. spumigena maintained its growth at all concentrations but after 3 weeks, a decrease in cell biomass and total peptides was observed. It may be due to shortage of stored phosphate within the cells.

It is recommended that the alteration in nitrate and phosphorus, can enhance the yield of intra and extracellular peptides and biomass in laboratories and can be helpful to control the bloom formation and toxin production in natural environments. Alter in nitrate and phosphorus conditions are also best to obtain the high amount of NOD and nodulopeptin 901. It is suggested that there is much work needed to know about the fate and use extracellular peptides. It is also recommended that to obtain highest amount of cell biomass, and intracellular and extracellular peptides, there is need to make some changes in recipe of BG-11 and time to harvest $N$. spumigena KAC 66 cultures. The role of toxin and other bioactive peptides by cyanobacteria is still unclear, potential use as signalling compounds or for defence against microorganisms that feed on cyanobacterial strains (Mundt et al. 2001).There is some information available on the fate of toxins released in surrounding medium. Sivonen and Jones (1999) studied degradation of NOD under different environmental conditions. They reported that under light and dark conditions NOD was photochemically degraded into smaller peptides, recycled by bacterial communities or maybe reused by cyanobacterial cell themselves.

The investigations on the growth limiting $\mathrm{N}_{2}$ or P nutrients and the response of the $N$. spumigena are still being unexplored. It was observed that $\approx 40-50 \%$ nodulopeptin 901 released consistently into the media. There are further investigations required to note the role of nodulopeptin 901 as a signalling compound. 


\section{References}

Allen MM, Stanier RY (1968) Growth and division of some unicellular blue green algae. J Gen Microbiol. pp 199-202.

Becker EW (1994) Microalgae, Biotechnology and microbiology. In: James B, Carr NH, Higgins IJ, Potters WG (eds.). Stud Biotechnol. Cambridge University Press, pp 291.

Bianchi TS, Engelhaupt E, Westman P, Andre' NT, Rolff C and Elmgren R. (2000) Cyanobacterial blooms in the Baltic Sea: Natural or human-induced? Limnol Oceanogr. 45:716-726.

Brutemark A, Vandelannoote A, Engström-Öst J, Suikkanen S (2015) A less saline Baltic Sea promotes cyanobacterial growth, hampers intracellular microcystin production, and leads to strain-specific differences in allelopathy. PLoS One 10: e0128904. 1:15.

Carmichael WW, Eschedor JT, Patterson GM, Moore RE (1988) Toxicity and partial structure of a hepatotoxic peptide produced by the cyanobacterium Nodularia spumigena Mertens emend. L575 from New Zealand. Appl. Environ. Microbiol. 54:2257-2263.

Eilola K, Meier HEM, Almroth E (2009) On the dynamics of oxygen, phosphorus and cyanobacteria in the Baltic Sea; A model study. J Mar Sys. 75:163-184.

Gupta N, Bhaskar ASB and Lakshmana RPV (2002) Growth characteristics and toxin production in batch cultures of Anabaena flos-aquae: effects of culture media and duration. World J Microbiol Biotech. 18:29-35.

Halinen K Fewer DP, SihvonenLM, Lyra C, Eronen E, Sivonen K (2008) Genetic diversity in strains of the genus Anabaena isolated from planktonic and benthic habitats of the Gulf of Finland (Baltic Sea). FEMS Microbio Ecol 64: 199- 208.

Halinen K, Jokela J, Fewer DP, Wahlsten M, Sivonen K (2007) Direct evidence for production of microcystins by Ananbaena strains from the Baltic Sea. Appl Environ Microbiol 73: 6543-6550.

Hameed S, Lawton LA, Edwards C, Khan J, Farooq U, Khan F (2017) Effects of temperature and salinity on the production of cell biomass, chlorophyll- $a$ and intra- and extracellular nodularins (NOD) and nodulopeptin 901 produced by Nodularia spumigena KAC 66. J Appl Phycol, 29: 1801-1810.

Henriksen P (2005) Estimating nodularin content of cyanobacterial blooms from abundance of Nodularia spumigena and its characteristic pigments-a case study from the Baltic entrance area. Harmful Algae. 4: 167-178.

Hobson P, Fallowfield HJ (2003) Effect of irradiance, temperature and salinity on growth and toxin production by Nodularia spumigena. Hydrobio, 493:7-15.

Karjalainen M (2005) Fate and effects of Nodularia spumigena and its toxin, nodularin, in Baltic Sea planktonic food webs, Finnish Institute of Marine Research, Finland, Helsinki. Pp. 33.

Kawachi M, Noël, M. H., (2005) Sterilization and sterile technique. In: R. A. Andersen (Ed.) Algal culturing techniques Chapter 5, Elsevier Academic Press, UK. Pp. 65-81.

Kivi K, KaitalaS, Kuosa H, Kuparinen J, Leskinen NE, Lignell R (1993) Nutrient limitation and grazing control of the Baltic planktonic community during annual succession. Limnol Oceanograph, 38:893905. 
Kononen K, Kuparinen J, Makela K, Laanemets J, Pavelson J, Nommann S (1996) Initiation of Cyanobacterial Blooms in a Frontal Region at the Entrance to the Gulf of Finland, Baltic Sea. Limnol Oceanograph, 41:98-112.

Kutser T (2009) Passive optical remote sensing of cyanobacteria and other intense phytoplankton blooms in coastal and inland waters. Internat J Remote Sensing, Pp. 4401-4425.

Lawton AL (1999) Determination of cyanobacteria in the laboratory. In. I Chorus, Bartram J (eds.) Toxic cyanobacteria in water: A guide toxic cyanobacteria in water: a guide to their public health consequences, monitoring and management. CRC Press, USA. Pp. 347-366.

Lehtimäki J (2000) Characterisation of cyanobacterial strains originating from the Baltic Sea with emphasis on Nodularia and its toxin, nodularin. Department of Applied Chemistry and Microbiology University of Helsinki Finland. Pp. 87.

Lehtimäki J, Moisander P, Sivonen K, Kononen K (1997) Growth, nitrogen fixation, and nodularin production by two Baltic Sea cyanobacteria. Appl Envron Microbiol, 63:1647-1656.

Lilover MJ and Stips A (2008) The variability of parameters controlling the cyanobacteria bloom biomass in the Baltic Sea. J Mar Sys, S108-S115.

Mazur-Marzec H, Kaczkowska M, Blaszczyk A, Akcaalan R, Spoof L, Meriluoto J (2013) Diversity of peptides produced by Nodularia spumigena from various geographical regions. Marine Drugs. 11: 119.

Mazur-Marzec H, Meriluoto J, Plinski M, Szafranek J (2006) Characterisation of nodularin variants in Nodularia spumigena from the Baltic Sea using liquid chromatography/mass spectrometry/mass spectrometry. Rapid Comm Mass Spectro, 20:2023-2032.

Mazur-MarzecH, Żeglińska L, Pliński M, (2005) The effect of salinity on the growth, toxin production, and morphology of Nodularia spumigena isolated from the Gulf of Gdańsk, Southern Baltic Sea. J Appl Phycol, 17: 171-179.

Mundt S, Kreitlow S, Nowotny A, Effmert U (2001) Biochemical and pharmacological investigations of selected cyanobacteria. Internat J Hyg Environ Health, 203:327-334.

Mur LR, Skulberg OM, Utkilen H (1999) Cyanobacteria in the environment. In: I Chorus, Bartram JE, Spon FN (eds.) Toxic cyanobacteria in water. A guide to their public health consequences, monitoring and management, London, Great Britain, WHO, Pp. 15-40.

Murphy RJ, Underwood AJ, Pinkerton MH, Range P (2005) Field spectrometry: New methods to investigate epilithic micro-algae on rocky shores. J Exp Mar Biol Ecol, 325:111-124.

Nausch M, Nausch G (2011) Dissolved phosphorus in the Baltic Sea-Occurrence and relevance. J Mar Sys, 87:37-46.

Olofsson M, Egardt J, Singh A, Ploug H (2016) Inorganic phosphorus enrichments in Baltic Sea water have large effects on growth, $\mathrm{C}$ and $\mathrm{N}_{2}$-fixation by Nodularia spumigena. Aquat Microb Ecol 77: 11123.

Rapala J, Sivonen K, Luukkainen R, Niemelä SI (1993) Anatoxin-a concentration in Anabaena and Aphanizomenon under different environmental conditions and comparison of growth by toxic and nontoxic Anabaena-strains-a laboratory study. J Appl Phycol. 5:581-591.

Rapala J, Sivonen K, Lyra C, Niemela SI (1997) Variation of microcystins, cyanobacterial hepatotoxins, in Anabaena as a function of growth stimuli. Appl Environ Microbiol, 63:2206-2212. 
Repka S, Mehtonen J, Vaitomaa J, Saari L, Sivonen K (2001) Effect of nutrients on growth and nodularin production of Nodularia strain GR8b. Microbial Ecol, 42, 606-613.

Repka S, Meyerhöfer M, von Bröckel K, Sivonen K (2004) Associations of cyanobacterial toxin, nodularin with environmental factors and zooplankton in the Baltic Sea. Microb Ecol, 47:350-358.

Schneider B, Kuss J (2004) Continental Shelf Research Past and present productivity of the Baltic Sea as inferred from $\mathrm{pCO}_{2}$ data. Cont Shelf Res, 24:1611-1622.

Sivonen K (1990) Effects of light, temperature, nitrate, orthophosphate and bacteria on the growth of the hepatotoxin by Oscillatoria agardhii strains. Appl Environ Microbiol, 56:2658-2666.

Sivonen K (1996) Cyanobacterial toxins and toxin production. Phycol, 35:12-24.

Sivonen K, Jones G (1999) Cyanobacterial Toxins. In I Chorus, Bartram J (eds.) Toxic Cyanobacteria in Water, A guide to their public health consequences, monitoring and management, Spon Press, London, pp 41-111.

Stal LJ, Albertano P, Bergman B, von Bröckel K, Gallon JR, Hayes PK, Sivonen K, Walsby AE (2003) BASIC: Baltic Sea cyanobacteria. An investigation of the structure and dynamics of water blooms of cyanobacteria in the Baltic Sea-responses to a changing environment. Cont Shelf Res, 23:1695-1714.

Stanier RY, Kunisawa R, Mandel M, Cohen-Bazire G (1971) Purification and properties of unicellular blue green algae (Order Chroococcales), Bacterio Rev, 35:171205.

Stolte W, Karlsson Ch, Carlsson P, Graneli E (2002) Modeling the increase of nodularin content in Baltic Sea Nodularia spumigena during stationary phase in phosphorus-limited batch cultures. FEMS Microbio Ecol, 41:211-220.

Teikari JE, Hou S, Wahlsten M, Hess, WR, Sivonen K (2018) Comparative genomics of the Baltic Sea toxic cyanobacteria Nodularia spumigena UHCC 0039 and its response to varying salinity. Front Microb, 9: 356.

Teikari JE, O"Sterholm J, Kopf M, Battchikova N, Wahlsten M, Aro E-M, Hess WR, Sivonen K (2015) Transcriptomic and proteomic profiling of Anabaena sp. strain 90 under inorganic phosphorus stress. Appl Environ Microb. 81: 5212-5222.

Vezie C, Rapala J, Vaitomaa J, SeitsonenJ, Sivonen K (2002) Effect of nitrogen and phosphorus on growth of toxic and nontoxic Microcystis starins and on intracellular microcystin concentrations. Microbial Ecol, 4:443-454.

Vintila S, El-Shehawy R (2010) Variability in the response of the cyanobacterium, Nodularia spumigena to nitrogen supplementation. J Environ Monitor. 12: 1885-1890.

Voß B, Bolhuis 2, Fewer DP. Kopf M, Mo“ke F, Haas F, El-Shehawy R, Hayes P, Bergman B, Sivonen K, Dittmann E, Scanlan DJ, Hagemann M, Stal LJ, Hess WR (2013) Insights into the physiology and ecology of the brackish-water-adapted cyanobacterium, Nodularia spumigena CCY9414 based on a genome-transcriptome analysis. PLoS One 8: e60224. 1-22.

Vuorio K, Lagus A, Lehtimäki JM, Suomela J, Helminen H (2005) phytoplankton community responses to nutrient and iron enrichment under different nitrogen to phosphorus ratios in the northern Baltic Sea. J Experi Mar Biol Ecol, 322:39-52. 
Wasmund N (1997) Occurrence of cyanobacterial blooms in the Baltic Sea in relation to environmental conditions. Internationale Revue der gesamten Hydrobi Hydrograpph, 82:169-184. 